\title{
The impact of technological and institutional transformation of the global financial market on education
}

\section{O impacto da transformação tecnológica e institucional do mercado financeiro global na educação}

\section{El impacto de la transformación tecnológica e institucional del mercado financiero mundial en la educación}

\author{
${ }^{1}$ Bashkir State University, Ufa, Russia. \\ ${ }^{2}$ Russian State University for the Humanities, Moscow, Russia. \\ ${ }^{3}$ Moscow State Regional University, Moscow, Russia. \\ ${ }^{4}$ M. Akmullah Bashkir State Pedagogical University, Ufa, Russia. \\ Corresponding author: \\ Asatur Albertovich Sukiasyan \\ Email: sukiasyan.a.a@mail.ru
}

Asatur Albertovich Sukiasyan ${ }^{1}$ (D) , Vitaly Fedorovich Ershov² (D), Vadim Eduardovich Poletaev ${ }^{3}$ (D) Maksim Sergeevich Menshikov ${ }^{4}$ iD , Rakhimyan Galimyanovich Yusupov ${ }^{1}$ iD

How to cite: Sukiasyan, A. A., Ershov, V. F., Poletaev, V. E., Menshikov, M. S., \& Yusupov, R. G. (2021). The impact of technological and institutional transformation of the global financial market on education. Revista Tempos e Espaços em Educação, 14(33), e16559. http://dx.doi.org/10.20952/revtee.v14i33.16559

\begin{abstract}
The article is devoted to forming new educational directions conditioned by the technological and institutional transformation of the global financial market in the 21st century. The modern digital economy puts forward new requirements for the competencies and professional ethics of specialists working in the investment sphere. The authors have identified the key factors determining the tasks of modernizing the training of financial analysts, bankers, and lawyers specializing in investment law. The problem concerns issues of digitalizing and globalizing investment flows, forming investment ecosystems, and expanding the participation of large financial businesses in educational projects. The authors conclude that global technological and socio-economic transformations stimulate the entire financial world, including Russia, to revise their business models, and the spheres of financial and specialized legal education - to actively modernize according to market requirements.
\end{abstract}

Keywords: Financial globalization. FinTech. Investment ecosystems. Professional investments. Financial education. 


\section{RESUMO}

O artigo se dedica a formar novos rumos educacionais condicionados pela transformação tecnológica e institucional do mercado financeiro global no século XXI. A moderna economia digital impõe novos requisitos para as competências e a ética profissional dos especialistas que atuam na esfera do investimento. Os autores identificaram os principais fatores que determinam as tarefas de modernização da formação de analistas financeiros, banqueiros e advogados especializados em direito de investimento. O problema diz respeito à digitalização e globalização dos fluxos de investimento, formação de ecossistemas de investimento e expansão da participação de grandes empresas financeiras em projetos educacionais. Os autores concluem que as transformações tecnológicas e socioeconômicas globais estimulam todo o mundo financeiro, incluindo a Rússia, a revisar seus modelos de negócios e as esferas da educação financeira e jurídica especializada - a se modernizar ativamente de acordo com as necessidades do mercad.

Palavras-chave: Globalização financeira. FinTech. Ecossistemas de investimento. Investimentos profissionais. Educação financeira.

\section{RESUMEN}

El artículo está dedicado a formar nuevas direcciones educativas condicionadas por la transformación tecnológica e institucional del mercado financiero global en el siglo XXI. La economía digital moderna plantea nuevos requisitos para las competencias y la ética profesional de los especialistas que trabajan en el ámbito de la inversión. Los autores han identificado los factores clave que determinan las tareas de modernización de la formación de analistas financieros, banqueros y abogados especialistas en derecho de inversiones. El problema tiene que ver con la digitalización y globalización de los flujos de inversión, la formación de ecosistemas de inversión y la ampliación de la participación de las grandes empresas financieras en proyectos educativos. Los autores concluyen que las transformaciones tecnológicas y socioeconómicas globales estimulan a todo el mundo financiero, incluida Rusia, a revisar sus modelos comerciales y las esferas de la educación financiera y jurídica especializada, para modernizarse activamente de acuerdo con los requisitos del mercado.

Palabras clave: Globalización financiera. FinTech. Ecosistemas de inversión. Inversiones profesionales. Educación financiera.

\section{INTRODUCTION}

The financial world of the $21^{\text {st }}$ century is rapidly changing under the influence of informatization and other trends in global development, leading, on the one hand, to the standardization of legal and technological operation parameters of banks, exchanges, and other financial institutions, and on the other - to the formation of many new models and forms of network interaction of the global capital market participants. Technological progress affects the structure of employment and economic relations of entire humanity (European Group on Ethics in Science and New Technologies, 2018, p. 12). This situation leaves its stamps on the professional financial community, whose representatives must constantly master additional competencies.

In the information space of international financial education, discussions are increasingly being held about new competencies and skills of specialists in the field of financial analytics, banking, etc. For example, for several years, experts from the CFA Institute, a leading international association of professional investors, have been studying these problems. The CFA Institute's research focuses on the issues of implementing new approaches to customer interaction and ethical standards of professional investment into the system of training specialists based on CFA programs (CFA Institute, 2016).

The relevance of this topic is constantly increasing due to the emergence of new institutions and instruments of the global financial market, such as economic ecosystems, green shares, etc. The 
head of the Russian Center of ACCA (Association of Chartered Certified Accountants) V. Starodubtseva (2018) emphasizes: "New trends create a completely different picture of the world, both for business and financial professionals... This process is already irreversible, and the only thing that financiers can do is to improve their competence and acquire new skills". In addition, the professionalism of employees of banking structures and international financial organizations is being seriously tested in the context of repeated global financial crises. The systems of economic and financial education, as well as the segments of the higher law school that train lawyers in the field of financial and corporate law and other specializations necessary for working in banks, as well as investment funds, and other institutions face arising certain challenges.

As the historiographical review, published in 2012 by J. Hastings, B. Madrian, and W. Skimmyhorn (2012) show, by the beginning of the second decade of the $21^{\text {st }}$ century, a fairly large international set of scientific literature devoted to the experience in developing financial education and enlightenment in the USA and other countries of the world had developed. In subsequent years, this topic has remained popular among economists, sociologists, and researchers dealing with educational problems. At that, in most publications of different years, priority attention is paid to educational programs and educational events that are aimed at developing personal finance management skills and involve schoolchildren, students (other than majoring in economics), representatives of various professions and social groups, etc. (Bernheim et al., 2001; Mandell, 2009; Sergeychik et al., 2015). An independent aspect of the problem concerns the skeptical nature of assessments of the role of financial education and enlightenment as a factor of economic growth of national economies and the personal well-being of asset holders, which is reflected in several scientific publications (Willis, 2011; Dew et al., 2020, etc.).

It should be noted that in the latest works of Russian authors, there is growing attention concerning the prospects of financial and economic education in the context of a post-industrial digital society. Thus, A. Stolyarova and G. Shahnazaryan (2010) reveal the global nature of the spreading process of financial literacy, which is reflected, in particular, in the desire of international organizations of a financial and economic nature, primarily the Organization for Economic Cooperation and Development (OECD) and the World Bank to create coordination mechanisms for activities in this area. Based on the experience of the Financial University under the Government of Russia, N.O. Voskresenskaya (2019) emphasizes the need to adjust existing educational programs and create qualitatively new models for training financiers. For Russia, Armenia, Kazakhstan, and other Eurasian states, the profession of a financier as such is relatively new and one of the most prestigious and popular fields of activity among young people, a symbol of progress and prosperity. Accordingly, discussions about the future of the rapidly changing global financial world and its actors are of particular interest to the intellectual community of these countries.

In general, the problems of the development of higher financial education, which largely determines the image of large companies and international financial systems, have now found only a fragmentary reflection in the scientific literature, and require additional study, which confirms the relevance of the chosen topic.

In the present article, the authors consider the problems and tasks that arise in the field of financial market professionals, using the example of investment ecosystems as one of the models of interaction between the investor community and the world of professional financiers represented by investment companies and banks. In the context of the problem under study, the article discusses the development of higher education areas that provide training for financial analysts, bankers, lawyers, and other specialists working in the investment business.

\section{METHODS}

As the study design, the authors proceeded from the situation that employing the case study method, it is possible to objectively describe the development trends in higher education. 
The study included the following stages: 1 . Choosing cases on the development proceeding from the transformation of the financial sector; 2 . Determining the parameters of a certain historical period of higher education development depending on the research criteria identified by the authors; 3.Collecting information consisting of empirical data based on statistical information and forecasts of experts, financial analysts, and bankers working in investment ecosystems.

\section{RESULTS AND DISCUSSION}

\section{Investment Ecosystems as a Factor of Changes in the System of Interaction between Investors and Financial Market Professionals}

In the mid-1990s, James Moore's theory of the economic ecosystem became known internationally (Moore, 1993, 1996). This theory is becoming increasingly popular with the development of electronic banking and financial globalization. A historical view of the development of financial technologies and the prospects for the impact of ecosystem principles on investment decisions are uncovered in the publications of Lee and Yong Jae Shin, S. Mamonov, and other FinTech innovation researchers (Lee \& Shin, 2018; Mamonov, 2020; Castro et al., 2020, etc.). Forming ecosystems in the financial sector of Russia is considered in detail in the publication of G.B. Kleiner, M.A. Rybachuk, and V.A. Karpinskaya (2020, p. 5), who note, in particular, that ecosystems are currently "becoming a new systemic actor of the economy and in the future will become the central link of the socio-economic landscape of the country".

A key factor in the emergence of financial ecosystems is the development of digital technologies that allow covering the widest possible range of Internet users with banking services and providing diverse information in the field of finance and investment. At that, it is obvious that the idea of a financial ecosystem is not limited to the frames of FinTech, affecting the philosophy of contemporary banking and investment business, and the relevant branches of education and enlightenment.

In the $21^{\text {st }}$ century, the principle of ecosystems, within which the interaction and joint development of companies and their customers take place, extends to the field of investment, which directly affects the problems of professional training of investment analysts and management. On the one hand, the development of investment ecosystems is dominated by the principle of CrowdWiz (wisdom of the crowd), which assumes direct access of investors to new market opportunities and management of their funds without the mediation of traditional investment consultants. As the innovative technology developers assume, for investment ecosystems, this reduces risks and increases investors' profits (ICO Kriptovalyuty, 2017). On the other hand, the emergence of open digital ecosystems poses new challenges for investment companies and banks, which must confirm their capabilities in the field of ensuring the interests of investors and strengthen their trust in financial market professionals. An independent aspect of contemporary world finance development consists in the competition of ecosystems among themselves. This phenomenon, which became the topic of one of the discussions at the St. Petersburg International Economic Forum 2018 (TASS, 2018), also puts forward additional requirements for specialists of banks and investment companies.

It should be noted that improving the financial literacy of citizens, especially young people, which has now become part of the state social policy of many countries and the object of intense attention of international organizations, is a kind of challenge for both investment companies and banks, as well as for specialized educational institutions that form the global financial elite. In the context of the digitalization of global finance, users of banking services and stock owners are getting more and more opportunities to make independent decisions and use the advanced achievements of FinTech. As noted by J. Graham, C. Harvey, and H. Huang (2009), stock owners with financial knowledge tend to diversify their investments and sell their assets more decisively on the market. The influence of the level of financial literacy on the choice of more profitable investment portfolios 
and the investment behavior of market participants, in general, was shown in some publications of the 2000s (Christelis et al., 2010; Vinichenko et al., 2020). As for the influence of financial knowledge on the nature of the interaction of asset owners with investment specialists, the available research and survey results are contradictory. Thus, the work of Miles S. Kimball and Tyler Shumway, based on the results of a 2005 survey, argues that more sophisticated and knowledgeable investors constantly behave as recommended by financial economists; they are also more likely to become independent players in the stock market. At the same time, "unknowledgeable investors simply make mistakes" (Kimball \& Shumway, 2010; Dudin et al., 2020). At the same time, the latest research by the CFA Institute shows that the level of customer confidence in professional investors and financial analysts is decreasing. According to skeptical owners of capital, investment intermediaries put the interests of their companies and personal income first, and do not consider it necessary to fully take into account the individual priorities of investors, such as concern for environmental protection, etc.

Thus, the trend of greater independence and activity in business decision-making, based on confidence in their competence, is being consolidated in the international community of financial asset owners. With the development of financial literacy of the trusters, their opportunities in the field of interaction with the staff of investment companies and banks, including in assessing the effectiveness of the actions of financial market professionals, are increasing. Thus, the traditional system of providing services to stock owners on the part of the investment business acquires the features of partnerships that require a certain update of approaches to the organization and methods of professional activity of financiers.

New requirements for professional competencies in the context of the digitalization of financial markets and the formation of economic ecosystems are also being formed with regard to lawyers working in investment companies and other financial structures. In legal practice, as well as in the field of finance, some functions are transferred to information services and robotic reference and analytical systems (Zagrebaeva, 2020, p. 44). At the same time, the demand for lawyers specializing in the field of information technologies, as well as experts on international financial law, including those working on improving and bringing together national investment legislation, is significantly increasing (Ruchkina \& Vengerovsky, 2015).

The services of investment lawyers, which are widely in demand, in particular, in Russia and other Eurasian countries that pursue a policy of attracting foreign capital to their economies, are of great importance for asset owners who are involved in the process of investing in legal and administrative regulation systems that are unfamiliar to them. Legal consulting as an independent type of business is capable of integrating into investment ecosystems, within which its development is determined by the general trends of dialogue with investors, such as a high level of professionalism, creative thinking, and business ethics.

\section{International Business and the Development of Financial Education}

Currently, leading investment companies and consulting centers are pursuing a policy of involving shareholders in asset management, while simultaneously improving the quality of their professional management to maximize the return on investment (Novick et al., 2018). The possibility of increasing the competence of capital owners is associated with a general increase in the financial literacy of the population, and direct activity in the field of placement and management of clients' funds is associated with the professionalism of the management and staff of investment companies and banks.

The leading positions among financial ecosystems are occupied by large American and Chinese companies that operate in the rapidly developing digital markets of the USA, Europe, Asia, and Latin America. These are Citi, Wells Fargo, Ant Financial, and Rakuten, as well as international payment systems of social networks, such as Facebook Pay, Google Pay, etc. Some of them, such as 
Standard Chartered and Ant Financial, are involved in lending and technological support for investment projects in Asia, Africa, the Middle East, and other regions of the world (Mamchits, 2020). Accordingly, their interest in the development of financial education and enlightenment is very high, which is expressed in the support of training programs and scientific and educational organizations.

Since 2016, Sberbank has been actively engaged in creating a digital ecosystem in Russia. Electronic services of Sberbank cover an increasingly wide range of needs of Russian society and business. Sberbank's educational initiatives include a Corporate University that implements, in particular, the "Digital Transformation of Business" Program, which includes the course "Digital Transformation of a New Reality "(together with INSEAD), the Chief Risk Officer School, etc. More than 400 responsible employees of Sberbank take part in the Program "Leaders Teach Leaders" (Sberbank's Corporate University, n.d.). As part of the Sberbank Roadmap, master classes on the achievements of FinTech and the prospects of the financial profession are held at the economic and financial faculties of universities in various cities of Russia. The idea of leadership which is achieved through self-development, responsibility, the ability to work in a team in combination with digital and other professional competencies, is being promoted among future financiers (Stavropol State Agrarian University, 2018).

The modernization of financial education is in the focus of ACCA experts, who have developed a set of recommendations for financial professionals. In this case, the problem of replacing the lower level of the financial business with artificial intelligence in the future was identified. This will cancel the usual educational stages - from basic education to the secondary and higher professional level of financial knowledge and raises the issue of creating new models for training top management. According to ACCA specialists, a significant factor influencing the profession of a financier is also adopting unified standards of financial activity and global business in general. The ACCA (2020) offers the financial community to focus on three basic areas of professional competencies, namely, corporate governance, professional ethics, and risk management. Interaction with customers, partners, and company personnel, based on compliance with ethical standards, individualization of approaches, support of confidence, is, as many experts note, one of the most important competitive advantages of a person over digital technologies. Along with the commitment to professional ethics, the ACCA (2020) encourages financiers to develop technical skills, intelligence, creativity, orientation in digital innovations, the ability to predict, and, at the same time, use the accumulated experience for business and personal growth.

An independent competitive attitude of a person in the world of electronic finance is emotional intelligence (EQ), which is based on the principles of awareness, self-esteem, motivation, and adaptability, which allow a financier to build a business strategy more successfully, implement his professional and personal potential (ACCA, 2020).

\section{Globalization of the Financial Education and Enlightenment System}

The experience of the leading countries of the world shows that financial enlightenment and education go alongside stimulating each other. The growing competence of financial services users increases the role of professionals as intermediaries and conductors in the world of complex information flows, alternative solutions, and high financial risks. Thus, the USA, where financial education has been conducted since the early 2000 s as one of the priorities of state policy attracting constant attention of leading banks, research centers, and charitable foundations (Ivashkin, 2015), is the world leader in elite financial education and science. In particular, specializations in the field of financial analytics and management are traditionally represented in the departments of economics at Harvard, Stanford, Princeton, and other leading American universities. These educational programs are included in the system of international academic exchanges and internships covering various countries of the world, such as Brazil, Great Britain, India, China, etc., 
and are also firmly integrated into the global network educational space (Finparty, 2016). This contributes to the formation of a broad professional outlook among graduates and the ability to work effectively within the framework of various models of financial markets, including within the framework of investment ecosystems.

Research on the experience sharing in the field of financial literacy support to create unified approaches to financial education is carried out by experts of the European Union in the context of the pan-European educational policy and programs for ensuring economic stability and development of the European region (European Economic and Social Committee, 2017).

Organization for Economic Cooperation and Development (OECD), and the World Bank have developed recommendations for states interested in implementing financial literacy programs. These recommendations became the basis for forming in the 2000s of global approaches to state strategies for supporting financial education and enlightenment, and unified international assessments of financial competencies. These strategies are based on the endeavors of states to pursue a policy of developing financial literacy of the population to follow the principles of an integrated approach to solving tasks, to ensure coordination of actions of all participants of the program, to conduct a detailed assessment of long-term and short-term priorities, taking into account best practices, to coordinate the development trajectories of the financial market and the financial literacy of services consumers, and to ensure information publicity in the preparation and implementation of educational programs (Stolyarova \& Shahnazaryan, 2010, p. 78).

Promising tasks of the development of financial education are reflected in the activities of international centers for training and advanced training of specialists in the field of finance, such as ICAEW, ACCA, and CFA Institute mentioned above, etc. In particular, the topic of updating the professional competencies of financiers in the context of forming investment ecosystems occupies a significant place in the analytical developments of the CFA Institute (CFA Institute \& Edelman, 2013).

Leading Russian universities are currently actively integrating into the global system of economic and financial education through academic exchanges, double degree programs, and international accreditation of basic and additional financial education programs. The leaders of this process are the Financial University under the Government of the Russian Federation, the Higher School of Management of St. Petersburg State University, and several other educational institutions whose financial programs have international accreditation and are included in international university ratings (QS Stars University Ratings, Financial Times Master in Management, etc.) (Financial Times, n.d.). The leading universities of Russia hold international scientific forums dedicated to the development prospects of the professional financial community. For example, on December 1, 2020, the Plekhanov Russian University of Economics together with ACCA Global, has organized an online round table "The Future of the Financial Profession", in the course of which participants discussed the signs of financial activity transformation in the context of digitalization of the economy, changes in the financial services sector, and high volatility of global markets. It is noteworthy that many speakers noted a thesis about the growing role of strategic functions and professional ethics of a financier in the context of the transformation of the traditional intermediary role of banks and investment companies (Plekhanov Russian University of Economics, 2020).

As for the professional training of lawyers involved in the field of financial business, at present, the programs "Investment Law", "Legal Regulation of Investment Activity", "International Financial Law", "International Investment Activity", etc. are being implemented in universities and specialized centers of legal and economic education in various countries. The specialization "Lawyer in the Field of Digital Economy" has gained popularity. This trend contributes to forming a body of lawyers to work in the post-industrial world, including within the framework of investment ecosystems and other global digital formats. It is noteworthy that according to the estimates of the Law Society (2020), the British association of solicitors, those law firms that rely on a transparent 
service and maximum understanding of customer requests, including through the use of digital Customer Relationship Management (CRM) systems, etc. soon will become the most competitive.

\section{CONCLUSIONS}

As a result of considering the estimates and forecasts currently existing in the expert community of financial business and educational organizations, it can be concluded that global technological and socio-economic transformations stimulate the entire financial world to revise its business models, and the financial education sector - to be actively modernized according to market requirements.

The factor of significant changes in the global financial business in the $21^{\text {st }}$ century is the national and international financial literacy programs, whose implementation covers most regions of the world, contributing to the direct involvement of millions of people in digital financial flows.

The investment ecosystem as an element of the digital economy and the business organization of a new type is a clear example of changing approaches to assessing the competence and effectiveness of various professional groups under the influence of information technologies and the principles of openness. Technologies that substitute specialists who were previously engaged in the financial business at the reference and organizational level significantly increase the requirements for financial analytics and management, legal investment consulting, bank management, etc. The prospect of the disappearance of the traditional financial world, including investment business, in the network space of FinTech and LawTech, determined the search for competitive advantages of a human - analyst, banker, legal consultant, etc. - against a computer.

According to the conducted research, at present, the international business and educational community has formed ideas about the effective participation of professionals in financial ecosystems, primarily based on creative solutions and following the norms of business ethics, while constantly mastering new digital technologies.

Accordingly, new programs and competencies, ideas about contemporary professional ethics are included all over the world in the programs of financial and legal education at universities. At that, those who receive certificates of specialized training in international centers for improving financial and legal qualifications assume the obligation to follow corporate ethical principles.

In the course of spreading the practice of investment ecosystems and the strengthening of business competition between them, it will become possible to more accurately and expressively assess the qualities and competencies that will determine the appearance of professionals in the financial world of the $21^{\text {st }}$ century.

Authors' Contributions: Sukiasyan, A. A.: conception and design, acquisition of data, analysis and interpretation of data, drafting the article, critical review of important intellectual content. Ershov, V. F.: conception and design, acquisition of data, analysis and interpretation of data, drafting the article, critical review of important intellectual content. Poletaev, V. E.: conception and design, acquisition of data, analysis and interpretation of data, drafting the article, critical review of important intellectual content. Menshikov, M. S.: conception and design, acquisition of data, analysis and interpretation of data, drafting the article, critical review of important intellectual content. Yusupov, R. G.: conception and design, acquisition of data, analysis and interpretation of data, drafting the article, critical review of important intellectual content. All authors have read and approved the final version of the manuscript.

Ethics Approval: Not applicable.

Acknowledgments: Not applicable.

\section{REFERENCES}

ACCA. (2020). Ethics and professionalism. Available: https://www.accaglobal.com/lk/en/qualifications/whyacca/competency-framework/competencies/ethics-and-professionalism.html 
Bernheim, B. D., Garrett, D. M., \& Maki, D. M. (2001). Education and saving: the long-term effect of high school financial curriculum mandates. Journal of Public Economics, 80(3), 435-465.

Castro, P., Rodrigues, J. P., \& Teixeira, J. G. (2020). Understanding FinTech ecosystem evolution through service innovation and socio-technical system perspective. In: Nóvoa, H., Drăgoicea, M., Kühl, N. (Eds.). Exploring service science. IESS 2020. Lecture notes in business information processing, vol. 377. Cham: Springer, pp. 187-201.

https://doi.org/10.1007/978-3-030-38724-2 14

CFA Institute. (2016). From trust to loyalty: a global survey of what investors want. Available:

https://www.cfainstitute.org/-/media/documents/survey/from-trust-to-loyalty.ashx

CFA Institute \& Edelman. (2013). Investor trust study. Available: https://www.cfainstitute.org/-

/media/documents/survey/cfa-institute-edelman-investor-trust-study-2013.ashx

Christelis, D., Jappelli, T., \& Padula, M. (2010). Cognitive abilities and portfolio choice. European Economy Review, 54(1), 18-38. http://dx.doi.org/10.1016/j.euroecorev.2009.04.001

Dew, J. P., Dean, L., Duncan, S. F., \& Britt-Lutter, S. (2020). A Review of effectiveness evidence in the financial helping fields. Family Relations, 69(3), 614-627. https://doi.org/10.1111/fare.12445

Dudin, M. N., Shakhov, O. F. Ivashchenko, N. P., \& Shakhova, M. S. (2020). Development of entrepreneurial competencies in the economy (evidence from digital entrepreneurship). Revista Inclusiones, 7(SI), 54-68.

European Economic and Social Committee. (2017). Financial education for all. Financial education strategies and best practices within the European Union. 2nd ed., 72 p. Available: https://www.eesc.europa.eu/en/our-

work/publications-other-work/publications/financial-education-all-second-edition

European Group on Ethics in Science and New Technologies (Ed.). (2018). Proceedings of the Open Round Table on the Future of Work, February 5, 2018. Luxembourg: Publications Office of the European Union, $50 \mathrm{p}$.

Financial Times. (n.d.). European Business School Rankings 2019. Available:

http://rankings.ft.com/businessschoolrankings/european-business-school-rankings-2019 (accessed December 2 , 2020).

Finparty. (March 30, 2016). The USA and Russia: comparison of the best financial universities of the two countries. Available: https://finparty.ru/mba/50288/ (accessed December 2, 2020).

Graham, J., Harvey, C., \& Huang, H. (2009). Investor competence, trading frequency, and home bias. Management Science, 55(7), 1094-1106. https://doi.org/10.1287/mnsc.1090.1009

Hastings, J. S., Madrian, B. C., \& Skimmyhorn, W. L. (September 2012). Financial literacy, financial education and economic outcomes. NBER Working Paper, no 18412. Available:

https://www.nber.org/system/files/working_papers/w18412/w18412.pdf

ICO Kriptovalyuty. (November 19, 2017). ICO overview of the CrowdWiz platform - Investments with collective decision-making. Available: https://ico-kriptovalyuty.ru/crowdwiz/ (accessed December 1, 2020).

Ivashkin, A. V. (September 1, 2015). The USA, as a stronghold of world financial literacy. Center for Military and Political Studies of MGIMO (U) of the Russian Foreign Ministry. Available: http://eurasian-defence.ru/?q=node/34324

Kimball, M. S., \& Shumway, T. (2010). Investor sophistication and the home bias, diversification, and employer stock puzzles. SSRN Electronic Journal, January, 29, 1-28. http://dx.doi.org/10.2139/ssrn.1572866

Kleiner, G., Rybachuk, M., \& Karpinskaya V. (2020). Ecosystem development in the financial sector of Russia. Manager, 11(4), 2-15. https://doi.org/10.29141/2218-5003-2020-11-4-1

The Law Society. (May 21, 2020). Using LawTech in your practice. Available:

https://www.lawsociety.org.uk/topics/client-care/using-lawtech-in-your-practice

Lee, I., \& Shin, Y. J. (2018). FinTech: Ecosystem, business models, investment decisions, and challenges. Business Horizons, 61(1), 35-46. http://dx.doi.org/10.1016/j.bushor.2017.09.003

Mamchits, R. (2020). The largest foreign financial ecosystem: results and plans for 2020. The National Banking Journal, 3(189), 21-25.

Mamonov, S. (2020). The role of information technology in FinTech innovation: insights from the New York City ecosystem. In: Hattingh, M., Matthee, M., Smuts, H., Pappas, I., Dwivedi, Y. K. (Eds). Responsible design, implementation and use of information and communication technology. I3E 2020. Lecture notes in computer science, vol. 12066. Cham: Springer, pp. 313-324. https://doi.org/10.1007/978-3-030-44999-5 26 
Mandell, L. (2009). The Financial literacy of young American adults. Results of the 2008 national jumpstart coalition survey of high school seniors and college students. Washington: Jumpstart Coalition.

Moore, J. (1993). Predators and prey: a new ecology of competition. Harvard Business Review, 71(3), 75-86.

Moore, J. (1996). The Death of competition: leadership and strategy in the age of business ecosystems. New York: Harper Business.

Novick, B., Edkins, M., \& Clark, T. (July 24, 2018). The investment stewardship ecosystem. Harvard Law School Forum on Corporate Governance. Available: https://corpgov.law.harvard.edu/2018/07/24/the-investment-stewardshipecosystem/

Plekhanov Russian University of Economics. (December 1, 2020). In the present - about the future: the development of the profession of a financier was discussed at PRUE. Available: https://www.rea.ru/ru/news/Pages/professiafinansist.aspx (accessed December 2, 2020).

Ruchkina, G., \& Vengerovsky E. (2015). Investment activities within the legal framework of the World Trade Organization. Russian Law Journal, 3(4), 124-149. http://dx.doi.org/10.17589/2309-8678-2015-3-4-124-149

Sberbank's Corporate University. (n.d.). Available: https://sberbankuniversity.ru/? ga=2.242124354.1764803960.1603227982-954542920.1603227982 (accessed December 1, 2020).

Sergeychik, S. I., Sergeychik, M. S., \& Maksimova, A. A. (2015). World experience in implementing projects in the field of financial education and improving the financial literacy of the population. Bulletin of Tomsk State University, 5(158), 35-41.

Starodubtseva, V. (November 2, 2018). If robots replace financiers, what will we expect in ten years? Business Platform Portal. Available: https://business-platform.ru/blog/esli-robotyi-zamenyat-finansistov,-chto-nas-zhdetcherez-10-let/ (accessed November 30, 2020).

Stavropol State Agrarian University. (April 24, 2018). Leadership is the necessary competence of the future financier. Available: http://www.stgau.ru/english/obschinf/news detail.php?ID=159984

Stolyarova, A. A., \& Shakhnazaryan, G. E. (2010). Analysis of the world practice of developing financial education and improving the financial literacy of the population. Finance and Credit, 34, 72-78.

TASS. (May 24, 2018). The digital future in finance: the struggle of ecosystems. Key conclusions. Available: tass.ru"pmef-2018/articles/5230441 (accessed December 1, 2020).

Vinichenko, M. V., Rybakova, M. V., Nikiporets-Takigawa, G. Yu., Chulanova, O. L., \& Lyapunova, N. V. (2020). The Influence of artificial intelligence on the human potential development: the views of orthodox clergy and parishioners. Cuestiones Políticas, 37(65), 400-418. http://dx.doi.org/10.46398/cuestpol.3865.27

Voskresenskaya, N. O. (2019). Financial and economic education in the digital future: the issue of popular professions and strategies for training financiers. In: Seregina, T. N., Orekhovskaya, N. A., Omarova, L. B. (Eds.). Proceedings of the scientific and methodological International Conference "Foresight of education: Academic freedoms against accreditation restrictions", April 20-27, 2019, Moscow, Russia. Moscow: Otechestvo, pp. 9-20.

Willis, L. E. (2011). The financial education fallacy. American Economic Review, 101(3), 429-434. http://dx.doi.org/10.1257/aer.101.3.429

Zagrebaeva, E. V. (2020). Artificial intelligence in corporate law as a virtual assistant when approving extraordinary transactions (a look into the future). Law and Digital Economy, 3(9), 44-49.

Received: 31 June 2021 | Accepted: 12 September 2021 | Published: 11 October 2021 